\title{
GAZİANTEP İLİ YERALTISULARININ HIDDOJEOKIMYASAL ÖZELLİKLERİ VE SU KALİTESİ
}

\author{
Şehnaz ŞENER ${ }^{1 *}$, Erhan ŞENER ${ }^{2}$, Arzu ER ${ }^{1}$ \\ ${ }^{1}$ Süleyman Demirel Üniversitesi, Mühendislik Fakültesi, Jeoloji Mühendisliği Bölümü, Isparta, Türkiye \\ 2 Süleyman Demirel Üniversitesi, Uzaktan Algılama Araştırma ve Uygulama Merkezi, Isparta, Türkiye
}

\begin{tabular}{l} 
Anahtar Kelimeler \\
\hline Hidrojeokimya, \\
Su kalitesi, \\
Yeraltisuyu, \\
Gaziantep.
\end{tabular}

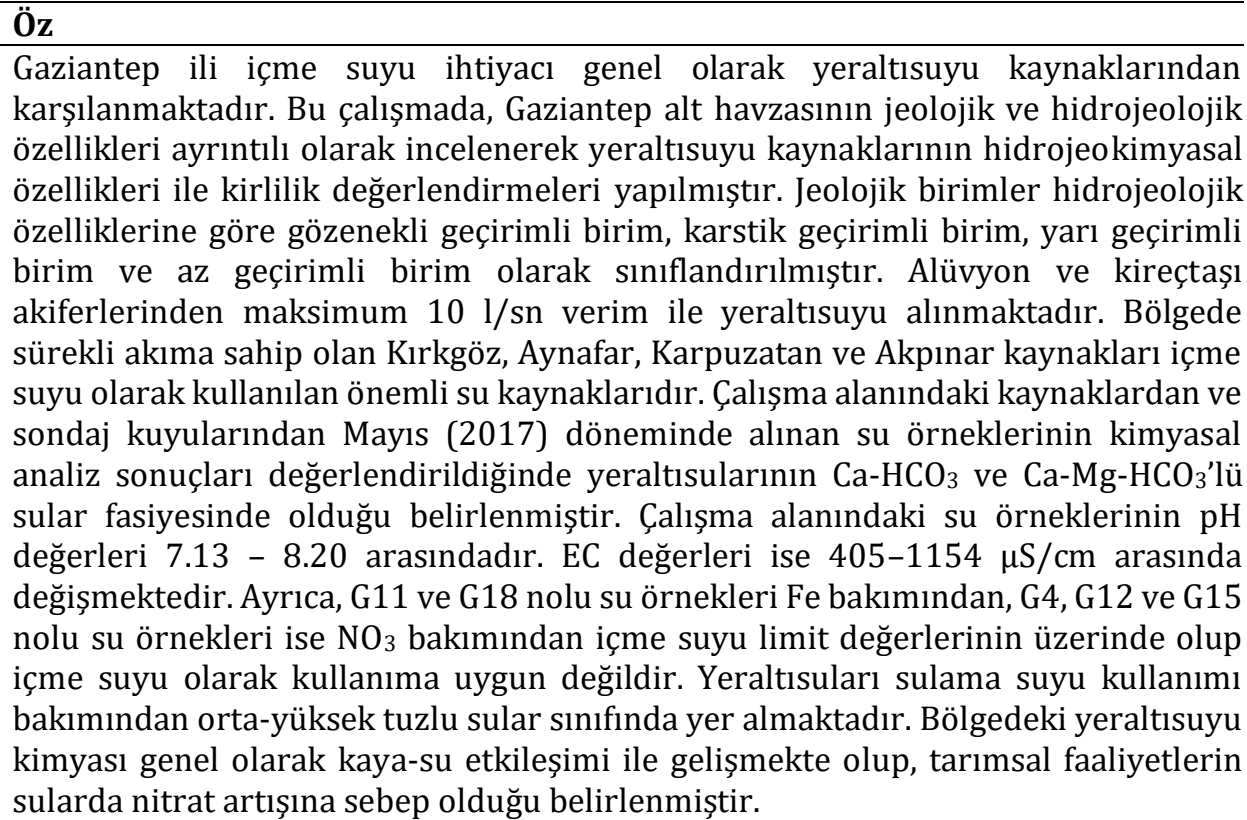

\section{HYDROGEOCHEMICAL PROPERTIES AND WATER QUALITY OF GAZIANTEP PROVINCE GROUNDWATERS}

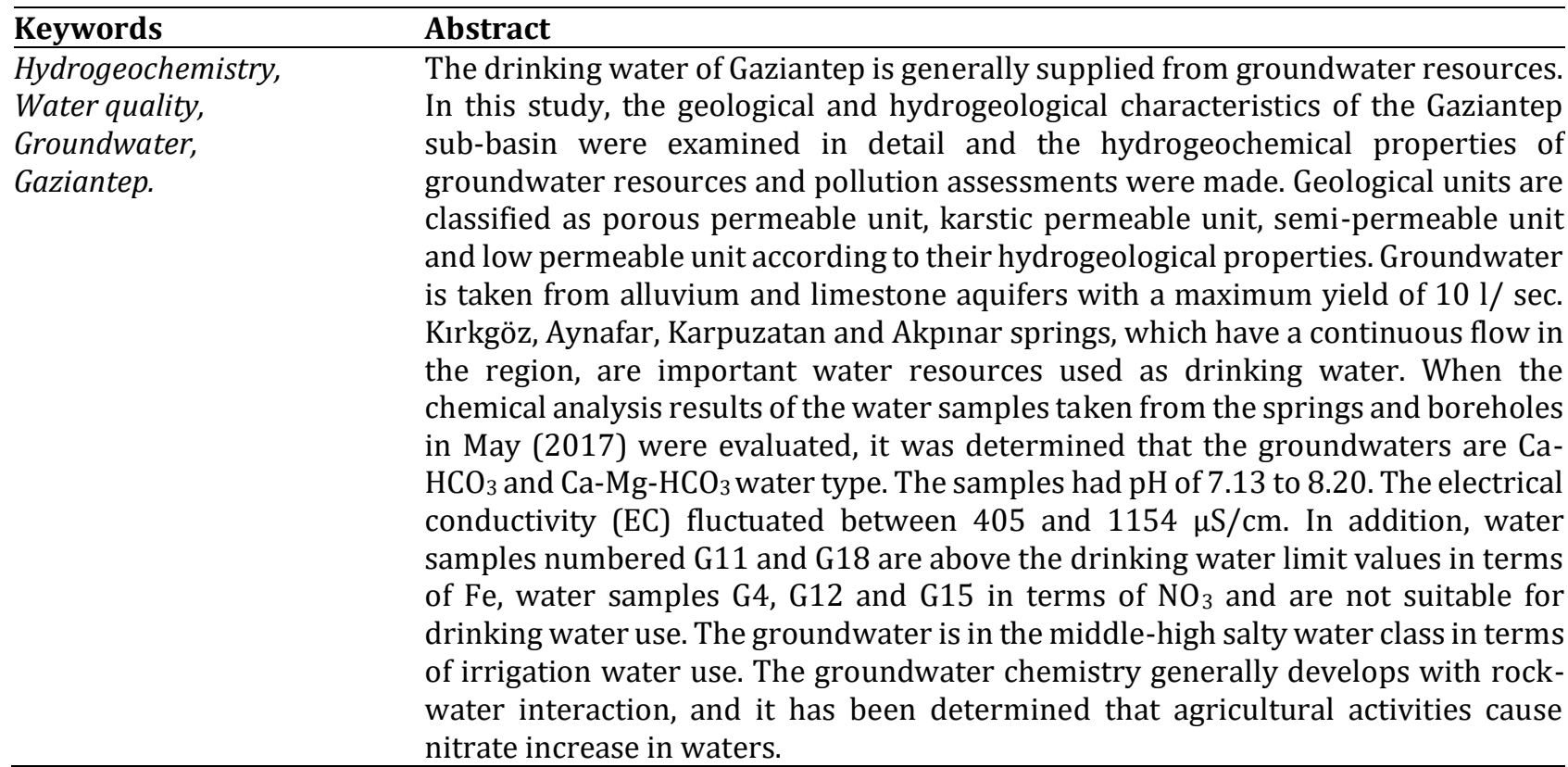

\footnotetext{
* ilgili yazar / Corresponding author: sehnazsener@sdu.edu.tr, +90-246-211-1332
} 


\section{Alıntı / Cite}

Şener, Ş., Şener, E., Er, A., (2021). Gaziantep İli Yeraltısularının Hidrojeokimyasal Özellikleri ve Su Kalitesi, Mühendislik Bilimleri ve Tasarım Dergisi, 9(4), 1253-1266.

\begin{tabular}{l|l|l}
\hline Yazar Kimliği / Author ID (ORCID Number) & \multicolumn{3}{|l}{ Makale Süreci / Article Process } \\
\hline Ş. Şener, 0000-0003-3191-2291 & Başuru Tarihi / Submission Date & 25.04 .2021 \\
E. Şener, 0000-0001-6263-8366 & Revizyon Tarihi / Revision Date & 02.08 .2021 \\
A. Er, 0000-0002-4749-7603 & Kabul Tarihi / Accepted Date & 05.08 .2021 \\
& Yayım Tarihi / Published Date & 20.12 .2021 \\
\hline
\end{tabular}

\section{Giriş (Introduction)}

Günümüzde, dünya genelinde olduğu gibi ülkemizde de küresel iklim değişikliğinin etkisiyle yüzey suyu kaynakları miktar olarak azalmaktadır. Bununla birlikte, kirleticilerden daha kolay etkilenen yüzey sularının kullanımı giderek sınırlanmaktadır. Bu durumda her türlü sektörde su ihtiyacının karșılanmasında yeraltısuları daha yoğun kullanılmaya başlanmıştır. Özellikle kentleşmenin yoğun olduğu bölgelerde nüfus artışıla orantılı olarak suya olan talebin artması kaçınılmazdır. Bununla birlikte kentleșmenin, tarımsal faaliyetlerin ve sanayinin yoğun olduğu bölgelerde su kirliliği en önemli problemlerden birisidir. Mevcut durumda özellikle içmesuyu ve tarımsal sulama ihtiyacının karşılanmasında yüzey sularının yanında yeraltısuları da kontrolsüz bir şekilde kullanılmaktadır (Jayaprakash vd., 2008; Srinivas vd., 2013). Ancak, herhangi bir doğal kaynak gibi yeraltısuları da sınırsız olmayıp hem nicelik hem de nitelik açısından akılcı bir su yönetimine ve planlamalarına ihtiyaç vardır. Yeraltısuyu kalitesi jeojenik ve antropojenik faktörlere bağlıdır (Vasanthavigar vd., 2010). Kaya-su etkileșimi gibi jeojenik faktörler ile evsel, tarımsal ve endüstriyel kirleticiler gibi antropojenik faktörler yeraltısuyu kalitesini olumsuz etkilemektedir (Şimş̧ek ve Gündüz 2007; Şener vd., 2009; Şener ve Davraz 2012; Bozdağ ve Göçmez, 2013; Bozdağ, 2016; Bozdağ, 2017). Özellikle yoğun gübre ve pestisit kullanımının gerçekleștiği tarımsal faaliyetlerin yaygın olduğu alanlarda yeraltısuları kirlenmeye maruz kalmaktadır (Fırat Ersoy ve Gültekin, 2013). Suyun farklı amaçlı kullanımlara uygunluğunun bilinmesi açısından suyun kimyasal özelliklerinin ve su kalitesinin belirlenmesi son derece önemlidir.

Bu çalışmada, Gaziantep ilinde içme ve sulama suyu olarak kullanılan yeraltısularının hidrojeolojik özellikleri incelenerek hidrojeokimyasal özellikleri, kalitesi ve kullanılabilirlik durumu araştırılmıștır. Çalışma alanında yeraltısuyu kaynaklarının hidrojeokimyasal özelliklerini ve su kalitesini belirlemeye yönelik bilimsel bir çalışma bulunmaması bu çalışmayı bilimsel açıdan özgün kılmaktadır.

\section{Kaynak Araștırması (Literature Survey)}

Çiftçi (2019) tarafından yapılan tez çalışmasında Gaziantep ili deprem master planının uygulanabilirliği incelenmiștir. Yapılan çalışmada, Gaziantep ili yerleșim alanlarının önemli ölçüde deprem üretebilecek aktif fay sistemlerine yakın olduğu ve bu nedenle de deprem riski taşıyan bölgede önlemlerin alınması gerektiği belirtilmektedir. Ayrıca hazırlanan master planların güncellenerek özellikle altyapı, imar planlamaları ve enerji sektörleri için geliştirilecek önlemlere uyulması gerektiği vurgulanmaktadır. Kafadar ve Saygıdeğer (2010) Gaziantep ilinde sulama suyu olarak kullanılan atık suların kurşun içeriklerini incelemişlerdir. Ayrıca, bu sularla sulanan bitkilerdeki ve temiz su ile sulanan bitkilerdeki kirlilik düzeylerini karşılaştırarak olası kurşun birikimlerini araştırmışlardır. Elde edilen sonuçlarda, atık sular ile sulanan bitkilerde önemli miktarlarda kurşun birikimi saptanmıştır. Alan (2017) tarafından yapılan tez çalışmasında ise Gaziantep ili Şehitkamil ilçesi için içme suyu şebekesi tasarımı geliştirilmiştir. Çalışmada, mevcut durumda Gaziantep ili içme suyu şebekesinden sağlanan suyun bölgedeki nüfus artışı dikkate alındığından yetersiz kalacağı ve bu nedenle bölgedeki kaynak sularının içme suyu olarak kullanımının gerekli olacağı belirtilmektedir.

Yapılan literatür araștırmalarında Gaziantep ili genelinde içme suyu ve sulama suyu olarak kullanılan yeraltısularının kimyasal özellikleri, su kalitesi ve kullanılabilirliğine yönelik bir çalışmaya rastlanmamıştır. Bu nedenle, Gaziantep ili yeraltısularının kullanım ve koruma planlamalarına önemli katkılar sağlayacak olan bu çalışma bölge için önem taşımaktadır.

\section{Materyal ve Yöntem (Material and Method)}

\section{1. Çalışma Alanı (The Study Area)}

Çalışma alanı olarak belirlenen Gaziantep alt havzası; 1/100 000 ölçekli Gaziantep-N38 ve Şanlıurfa-N39 paftalar ve bu paftaların 1:25 000 ölçekli N38-c4, N38-c3, 038-a2, 038-b1, 038-b2, 038-a1, 038-b4, 039-a4, 039-a3, 039d1 topoğrafik haritalarını kapsar. Çalışma alanına ait yerbulduru haritası Şekil 1'de verilmiştir. Gaziantep alt 
havzası 480-1300 m kotları arasında yer alır. Alt havzanın; kuzey batıda Taşkın tepe (1100 m), batıda Tepecibayır tepe (1028 m), Kara tepe (999 m), güneyde Kıraç tepe (848 m), Keşifçi tepe (817 m), Almalı tepe (881 m), doğuda Ziyaret tepe (988 m), Yürükdağ tepe (863 m), Yoğunhüyük tepe $(782 \mathrm{~m})$, güneydoğuda Barak dağı $(663 \mathrm{~m})$ başlıca yükseltilerini oluşturur. İnceleme alanında yerleşim birimleri Gaziantep İl Merkezi, Şahinbey, Şehitkamil, Oğuzeli ilçeleri ve çok sayıda mahalle, su noktaları Tüzelsuyu deresi, Sacirsuyu çayı ile akımları sürekli Kırkgöz, Aynafar, Karpuzatan, Akpınar (Cağdın) ve akımları yağışların az olduğu yıllarda sürekli olmayan Enebacı ve Çapalı kaynaklarıdır. Gaziantep alt havzasının doğu-güney-güneybatısında alt havzanın \% 74,20'sini temsil eden düz alanlar ova alanını oluşturur (DSİ, 2018).

Gaziantep alt havzası sınırları içerisinde 17261 nolu Gaziantep (Kot $855 \mathrm{~m}$ ) Devlet Meteoroloji İstasyonunun 1939-2013 yılları arasında yağış verilerine göre, ortalama yıllık yağış 553,04 mm, en düşük aylık ortalama yağış 2,03 mm ile Temmuz ayında, en yüksek aylık ortalama yağış 101,57 mm ile Aralık ayında gerçekleşmiştir. 1962 2010 yılları arasında ölçülen buharlaşma verilerine göre ortalama yıllık toplam buharlaşma 1425 mm, en yüksek aylık toplam buharlaşma 305,3 mm ile Temmuz ayında, en düşük aylık toplam buharlaşma 17,9 mm ile Aralık ayında gerçekleşmiştir. 1940-2010 yılları arasında ölçülen sıcaklık değerlerine göre yıllık ortalama sıcaklık $14,8^{\circ} \mathrm{C}$, en düşük aylık ortalama sıcaklık $2,8^{\circ} \mathrm{C}$ ile Ocak ayında, en yüksek aylık ortalama sıcaklık $27,5^{\circ} \mathrm{C}$ ile Temmuz ayında gerçekleşmiştir. 18285 nolu Oğuzeli DMİ 1962-1983 yılları arasındaki yağış verilerinin aritmetik ortalamasına göre ortalama yıllık yağış 456,14 mm, en düşük aylık ortalama yağış 5,02 mm ile Eylül ayında, en yüksek aylık ortalama yağış 92,88 mm ile Aralık ayında gerçekleşmiştir. 1965-1992 yılları arasında ölçülen sıcaklık değerlerine göre ortalama sıcaklık $15^{\circ} \mathrm{C}$, en düşük aylık ortalama sıcaklık $2,9^{\circ} \mathrm{C}$ ile Ocak ayında, en yüksek aylık ortalama sıcaklık $26,5^{\circ} \mathrm{C}$ ile Temmuz ayında gerçekleşmiştir (DSİ, 2018).

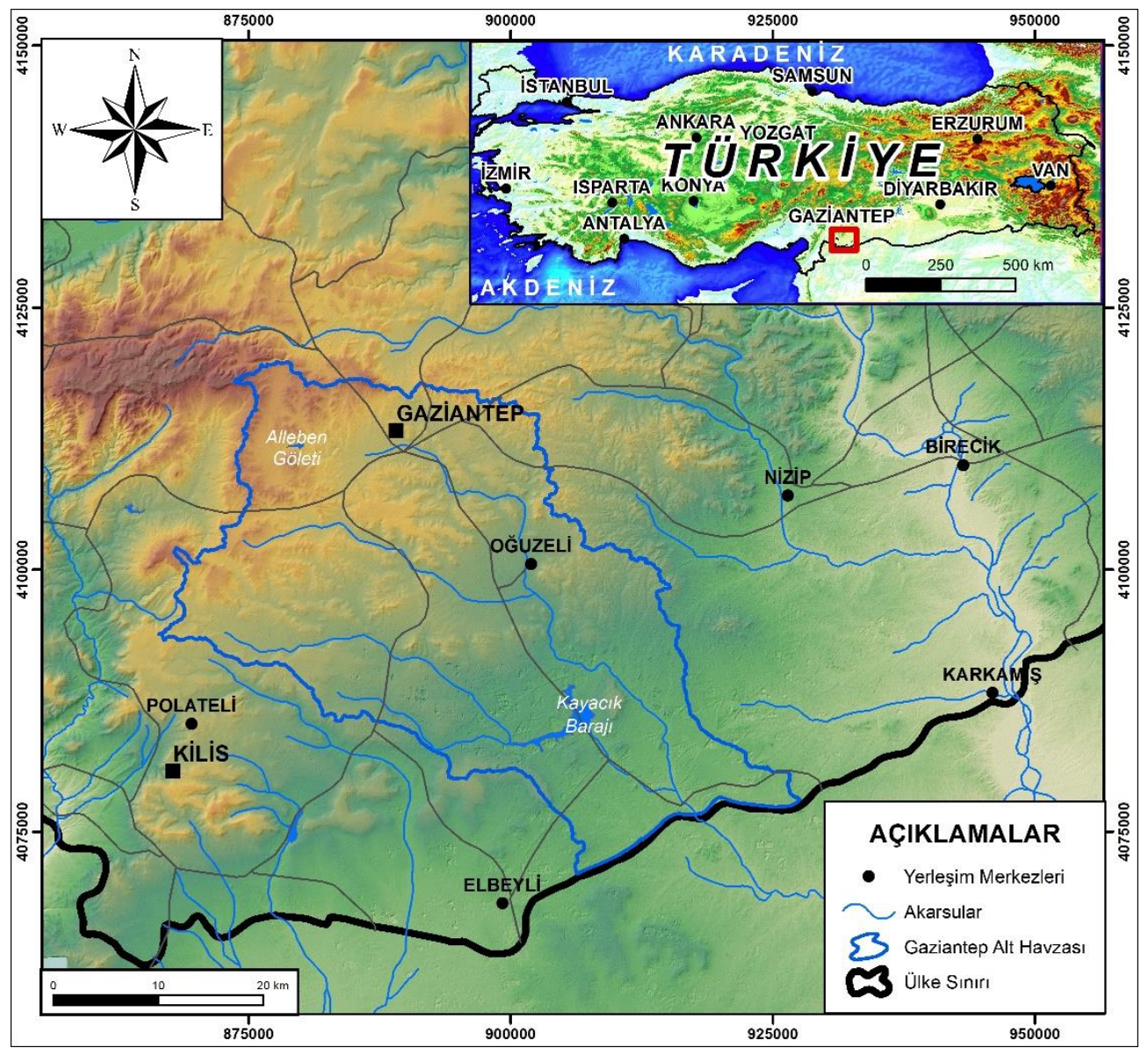

Şekil 1. Çalışma alanının yerbulduru haritası (Location map of the study area)

\section{2. Çalışma Yöntemleri (Methods)}

Gaziantep ili içmesuyu kaynaklarının hidrojeokimyasal özelliklerini ve su kalitesini ortaya koyabilmek için öncelikle çalışma alanında yüzeyleyen formasyonlar ve bunların litolojik özellikleri incelenmiş ve jeoloji haritası hazırlanmıştır. Bölgede bulunan kaynaklar ve bu kaynaklara ait hidrolojik bilgiler literatür çalışması ile elde edilmiştir. Litolojik birimlerin akifer olabilme potansiyelleri değerlendirilerek çalışma alanının hidrojeolojik haritası oluşturulmuştur. Çalışma alanındaki yeraltısularının kimyasal yapısını, kullanım özellikleri ve kalitesinin belirlenmesi amacıyla çalışma alanı içerisindeki içmesuyu olarak kullanılan kaynak ve yeraltısularından Mayıs- 
2017 döneminde toplam 21 farklı lokasyondan su örnekleri alınmıştır. Su örneklerin kimyasal analizleri Bureau Veritas Mineral (Kanada) laboratuvarı ve Süleyman Demirel Üniversitesi Jeotermal Enerji, Yeraltısuyu ve Mineral Kaynakları Araştırma ve Uygulama Merkezi laboratuvarında yaptırılmıştır. Ayrıca arazide numune alımı sırasında suların, sıcaklık (T), elektriksel iletkenlik (EC) ve hidrojen iyonu konsantrasyonu (pH) değerleri YSI Professional Plus marka çok parametreli portatif su kalitesi ölçüm cihazı kullanılarak yerinde ölçümler ile belirlenmiştir. Su örneklerinin hidrojeokimyasal özelliklerinin belirlenmesinde anyon ve katyon analiz sonuçları Piper (1944) ve Gibbs diyagramları üzerine yerleştirilerek yorumlanmıştır. Suların içme suyu ve sulama suyu olarak kullanılabilirliğinin belirlenmesi için ulusal ve uluslararası standartlar ile belirlenen limit değerler ile karşılaştırmanın yanı sıra Özgül Elektriksel İletkenlik (EC) değerleri ve ABD tuzluluk diyagramı kullanılmıştır.

\section{Araştırma Bulguları (Research Findings)}

\subsection{Jeolojik Özellikler (Geological Properties)}

Çalışma alanı ve yakın çevresi farklı araştırmacılar tarafından jeolojik ve stratigrafik özellikleri açısından incelenmiştir. Yapılan tüm bu çalışmalar incelenerek, elde edilen bilgiler arazi çalışmaları ile desteklenmiş ve bölgenin 1/50 000 ölçek hassasiyetinde hazırlanmış jeoloji haritası Şekil 2'de sunulmuştur. Çalışma alanında Üst Kretase, Paleojen, Neojen, Kuvaterner yaşlı sedimanterler ve magmatik kaya birimleri yüzeylenmektedir. Sedimanter kaya birimleri yaşlıdan gence doğru Üst Kretase-Paleosen yaşlı marn, Eosen yaşlı killi çakıltaşı-çakıllı kireçtaşı-tebeşirli kireçtaşı- kavkılı kireçtaşı, Oligosen yaşlı marn-marnlı kireçtaşı-tebeșirli kireçtaşı, Miyosen yaşlı kireçtaşı, Üst Miyosen yaşlı çakıltaşı-kumtaşı-şeyl-çakıllı kiltaşı, Pliyokuvaterner yaşlı eski alüvyon, Kuvaterner yaşlı alüvyon, magmatik kaya birimleri ise Miyosen yaşlı bazaltlarla temsil olunur (MTA 1996, 1997).

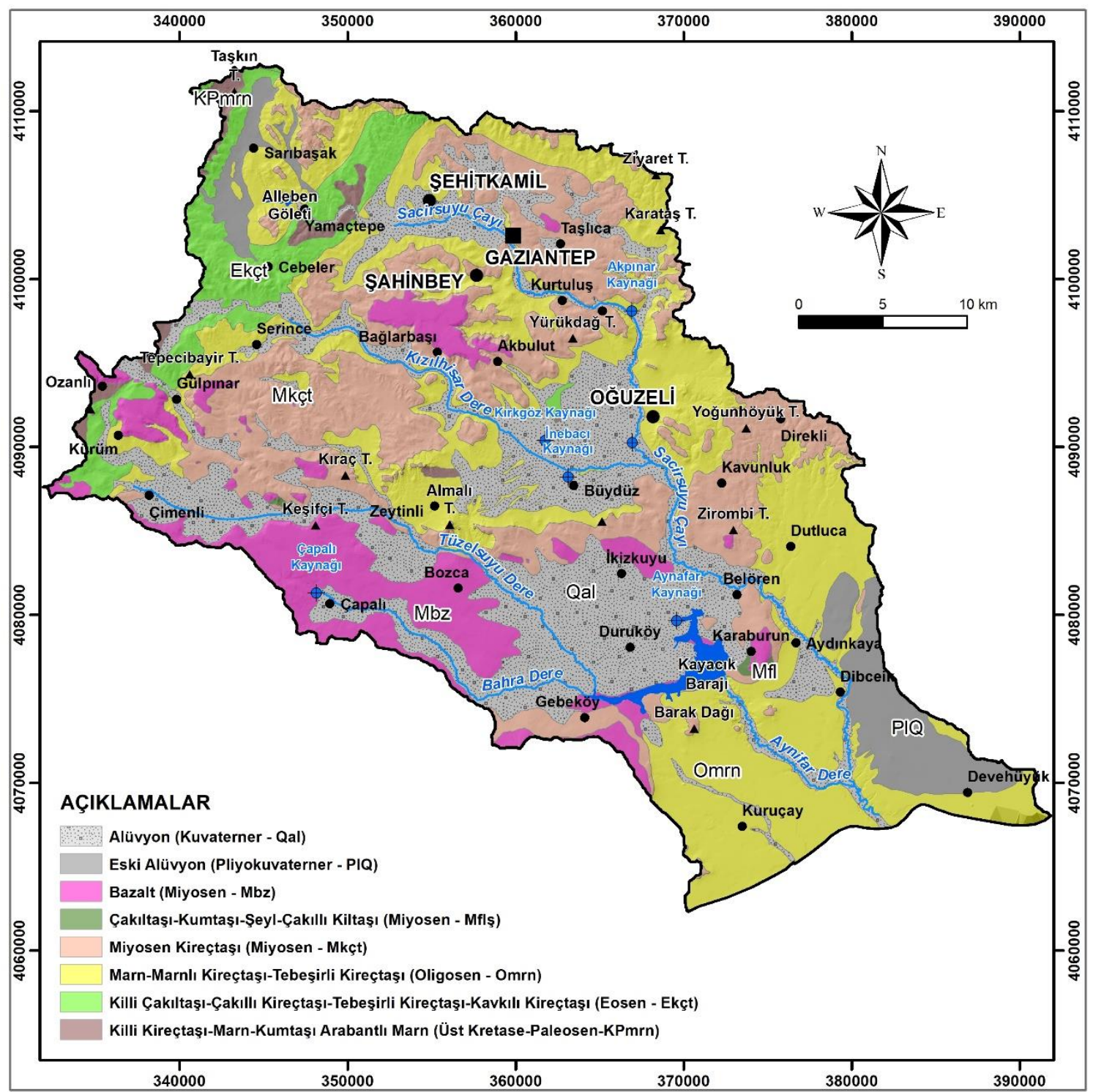

Şekil 2. Çalıșma alanının jeoloji haritası (Geological map of the study area) (MTA 1996, 1997) 
Çalışma alanında tabanda bulunan killi kireçtaşı-marn-kumtaşı arabantlı marn (KPmm), çalışma alanında batıkuzeybatı ve orta kesimlerde toplam 16,16 km² alanda yüzeylenmektedir. Birimin taban seviyeleri krem bej renkli, sert-yumuşak, milli, kalın tabakalı, serpantin-kireçtaşı ve çakıltaşı arabantlı kumlu tebeşirler gözlenmektedir. Orta seviyeleri açık gri renkli, yumuşak, milli, mikalı ince şeyl ve kumlu kireçtașı ara tabakalı, ince-orta-kalın tabakalı marn, üst seviyeleri ise pembe, gri renkli, tebeşir ara tabakalı, yer yer açık yeşil-gri renkli ince tabakalı, çört yumrulu marn ara tabakalı killi kireçtaşı kaya türlerinden oluşur. Yaklașık 150-500 m arasında değișen kalınlıktaki birimin tavan dokanağı Eosen yaşlı birimlerle uyumludur (MTA 1996, 1997). Killi çakıltaşı-çakıllı kireçtaşıtebeşirli kireçtaşı-kavkılı kireçtaşı (Ekçt) birimleri, bölgenin batı-kuzeybatı ve orta kesimlerde toplam 77,69 km² alanda yüzeylenmektedir. Birim tabandan itibaren açık gri, kahve renkli çakıltaşı, yumuşak-dağılgan, milli, killi çörtlü, taban seviyeleri çört-marn ardalanmalı killi kireçtaşı orta seviyeleri tebeşirli kireçtaşı, üst seviyeleri açık kahve, sarı, gri, bej renkli kalın-çok kalın tabakalı yer yer masif, gözenekli, erime boşluklu, kavkılı, kırık ve çatlaklı kireçtaşı kaya türlerinden oluşur. 100-500 m arasında değişen kalınlıktaki birimin taban dokanağı Üst KretasePaleosen, tavan dokanağı Oligosen yașlı birimlerle uyumludur (MTA 1996, 1997). Marn-marnlı kireçtașı-tebeșirli kireçtașı (Omrn) toplam 426,85 km² alanda yüzeylenmektedir. Birim tabandan itibaren açık gri renkli, yumuşak, milli-killi, marn-çört ardalanmalı marn-marnlı kireçtaşı, üst seviyeleri killi-tebeşirli kireçtaşı kaya türlerinde oluşur. Hakim kaya türü marnlardır. Havza kenarı veya derin şelf kenarı mikrofasiyes ortamında çökelmiştir. 100 250 m arasında değişen kalınlıktaki birim, Eosen yaşlı birimler üzerine uyumlu bir dokanakla yer alır. Miyosen Kireçtaşı (Mkçt) birimi 312,42 km²'lik alana sahip olup birim alttan üste doğru krem, beyazımsı-kirli sarı renkli orta-kalın tabakalı, çört yumrulu, masif kireçtaşı, kirli sarı renkli orta-kalın tabakalı çört yumrulu, fosil kavkılı kireçtaşı, üst seviyeleri beyazımsı krem-kirli sarı renkli, kalın-çok kalın tabakalı, az çört yumrulu, bol Ekinit fosilli kireçtaşlarından oluşur. Çalkantılı sı̆̆ su mikrofasiyes ortamında çökelen birimin kalınlığı 0-150 m arasında değişir. Oligosen yaşlı birimler üzerinde uyumlu bir dokanakla yer alır (MTA 1996, 1997).

Çakıltaşı-Kumtaşı-Şeyl-Çakıllı Kiltaşı (Mflş) birimlerinden oluşan Miyosen filişleri çalışma alanının güneyinde Karadibek ve Mağaracık çevresinde 2,70 km² alanda yüzeylenmektedir. Çakıltaşı, kumtaşı, şeyl ardalanmalı akarsu ile kumtașı, marn gibi göl çökellerinin ardalanmasından olușur. Yanal ve dikey geçișli olan birimin kalınlığının 0 150 m arasında değişir. Miyosen yașlı birimler üzerinde uyumlu bir dokanakla yer alır (MTA 1996, 1997). Filiș birimlerin üzerinde bulunan bazaltlar (Mbz) yaklaşık 134,51 km² alanda yüzeylenmektedir. Kırmızımsı, koyu kahve, koyu gri ve siyahımsı renkte, tabakasız, yer yer tabakalı, gözenekli, lav akıntıları, yer yer aglomera ve tüf ara bantlı yüzeylenmelerinden oluşur. Kalınlığı 0-150 m arasında değișir. Üst Miyosen-Pliyosen yaşlı olan bazaltlar daha yaşlı birimler üzerinde açısal uyumsuzlukla yer alır (MTA 1996, 1997). Kuvaterner örtü birimlerinden Eski Alüvyon (PlQ) ovanın güney doğusu ve kuzey batısında toplam 69,96 km²'lik alanda yüzeylenmektedir. Akarsuların eski yataklarında ve düzlüklerde gevşek tutturulmuş çakıltaşı-kumtaşı-çamurtaşlarından oluşan birimin kalınlığı 0-80 m arasında değişir. Alüvyon (Qal) ise Tüzelsuyu dere, Sacirsuyu çayı ile yan kollarının vadi ve yataklarında tutturulmamış güncel çakıl, kum, çamur depozitlerinden oluşur. Çalışma alanında 362,09 km² alanda yüzeylenen birimin kalınlığı 0-10 m arasında değişmektedir (MTA 1996, 1997).

\subsection{Hidrojeolojik Özellikler (Hydrogeological Properties)}

\subsubsection{Su Noktaları (Water Points)}

Çalışma alanı içerisindeki en önemli su noktaları Tüzelsuyu dere, Sacirsuyu çayı, akımları sürekli olan Kırkgöz, Aynafar, Karpuzatan, Akpınar (Cağdın) kaynakları ve yağışların az olduğu dönemlerde sürekli akımları olmayan Enebacı ve Çapalı kaynaklarıdır.

\subsubsection{Akarsular}

Tüzelsuyu dere, çalışma alanının güney batısından Çimenli, Şahinbey, Yeşil mahalleleri çevrelerinde küçük debili kaynak akımlarından oluşur. Güneydoğu yönünde Bahre dere akımlarıyla birleșip Kayacık barajı rezervuarına akar. Kayacık barajı inșa edilmeden önce Aynafar kaynağı akımlarının katılımıyla güney yönünde akarak Akçakoyunlu mahallesi yakınlarında Sacirsuyu çayına katılır. Tüzelsuyu deresi en yüksek yıllık ortalama akımı 2,235 m³/s ile 1968 yılında, en düşük yıllık ortalama akımı 0,036 m³/s ile 1983 yılında gerçekleşmiştir. Tüzelsuyu deresi 1979-1984 yılları arasında Temmuz, Ağustos ve Eylül aylarında kurudur (DSİ, 2018).

Gaziantep il merkezi batısında Pancarlı ve İbrahimli mahalleleri çevrelerinden doğan Sacirsuyu çayı, doğu ve güneydoğu istikametinde akarak Gaziantep il merkezi, Oğuzeli ilçe merkezi ve yakın çevrelerindeki mahallelerin atık sularının katılımından sonra güney yönünde ilerleyip Akçakoyunlu mahallesi güneyinden Suriye topraklarına girer. Drenaj alanı $999 \mathrm{~km}^{2}$ 'dir. Sacirsuyu çayının en yüksek ortalama yıllık akımı 9,925 m³/s ile 1969 yılında, en düşük akım değeri ise 2,451 m³/s ile 1966 yılında gerçekleşmiştir. Sacirsuyu çayı Aralık-Mayıs döneminde en yüksek akım değerlerine ulaşmaktadır (DSi், 2018). 


\subsubsection{Kaynaklar}

Kırkgöz Kaynağı; Oğuzeli ilçesi Sazgın mahallesinin takriben 2 km kuzeybatısında Eosen yaşlı çakıltaşları ile Paleosen yaşlı marnların kontağından 698,33 m kotunda birden fazla noktadan boşalmaktadır. Kaynaktan kaptaj yapılarak içme-kullanma suyu olarak kullanılmakta, bir kısmı ise Sazgın civarındaki arazilerde tarımsal sulama suyu olarak kullanılmaktadır. Aynafar Kaynağı; Oğuzeli ilçesinin Yukarıüneyse mahallesinin 2 km kuzeyinde Pliyo-Kuvaterner birimlerden 598,10 m kotunda birden fazla gözden boşalmaktadır. Kaynak yağışların fazla olduğu kış aylarında Kayacık barajını da beslmektedir. İçme-kullanma ve sulama suyu ihtiyacının karşılanmasında kullanılan Aynafar kaynağı, Kayacık barajındaki su seviyesi maksimum değerlere ulaştığında büyük oranda su altında kalmaktadır. Kaynağın maksimum ortalama akımı 472,83 l/s ile 1996 yılında, minimum ortalama akımı 304,50 l/s 1990 yılında gerçekleșmiştir. Aynafar kaynağı rezervuarında yüzeylenen jeolojik birimlerde karstlaşma az-orta derecede gelişmiştir (DSİ, 2018).

Karpuzatan Kaynağı; Oğuzeli ilçesinin 1 km güneybatısında Pliyo-Kuvaterner yașlı birimlerden 656,41 m kotunda birden fazla gözden kaynayarak boşalmaktadır. Kaynak akımları ile yaklaşık 200 hektar tarım alanı sulanmaktadır. Tarımsal sulama mevsimi dışında kaynak suları Sacirsuyu çayına karışır. Kaynak akımları Aralık-Haziran ayları arasındaki dönemde en yüksek, diğer aylarda ise birbirlerine yakın değerlerdedir. Kaynağın maksimum ortalama akımı 413,50 l/s ile 1995 yılında, minimum ortalama akımı 146,40 l/s 1991 yılında gerçekleşmiştir. Orta değişken kaynak özelliğindeki Karpuzatan kaynağı rezervuarında yüzeylenen jeolojik birimlerde karstlașma az-orta derecede gelişmiştir. Yeraltısuyu hareketinin eklem ve çatlaklar boyunca olduğu, yüzey drenaj alanından daha geniş bir alandan beslendiği söylenebilir. Yağıșlar kısa sürede ve kaynak akımlarını etkilemekle beraber 1-2 ay gecikmeli olarak ta etkiler. Yağıșların az veya olmadığı aylarda kaynak akımları büyük boyutta azalır (DSİ, 2018).

Akpınar (Cağdın) Kaynağı; Oğuzeli ilçesinin 7 km kuzeyinde Akpınar mahallesinde Oligosen yaşlı tebeșirli-killi kireçtaşlarından 724 m kotunda birden fazla noktadan boşalmakta ve akış göstermektedir. Kaynak sularının yaklaşı 100 l/s'si Oğuzeli ilçe merkezleri ve Barak grubu mahallelerinin içme-kullanma suyu olarak kullanılmakta, geri kalan kısmı ise tarımsal sulamada kullanılmaktadır. Akpınar (Cağdın) kaynağının maksimum yıllık ortalama akımı 396,10 l/s ile 2002 yılında, minimum akımı ise 123,40 l/s ile 2009 yılında gerçekleșmiştir. Enebacı Kaynağı; Oğuzeli-Sazgın mahallesinin 1,5 km güneyinde Oligosen yaşlı tebeşirli kireçtaşı çatlaklarından yarımay şeklindeki bir zondan belirgin 4 noktadan boșalmaktadır. Yağıșın az olduğu yıllarda debisi azalan veya kuruyan kaynağın ortalama debisi 43 l/s'dir. Kaynak tarım alanlarının sulanmasında kullanılmakta, sulama mevsimi dışında ise kaynak suları Kızılhisar deresine karışmaktadır. Çapalı Kaynağı; Gaziantep alt havzasının güneybatısında Çapalı mahallesinin $1 \mathrm{~km}$ kuzeybatısında $710 \mathrm{~m}$ kotunda birden fazla gözden bazalt biriminin kırık ve çatlaklarından boşalmaktadır. Çapalı kaynağı yakın çevresinde tarımsal sulamada kullanılmaktadır. Sulama mevsimi dışında ise Bahra deresine karışmaktadır (DSİ, 2018).

\subsubsection{Kuyular (Wells)}

Çalışma alanında özellikle şehir merkezinde bulunmak üzere toplam 94 adet olan sığ kuyuların derinlikleri $10 \mathrm{~m}$ ve daha azdır. Ayrıca, Devlet Su İşleri (DSİ), İl Özel İdaresi, GASKİ ve Özel şahıslar tarafından 24-275 m arasında değişen derinliklerde açılmış olan çok sayıda sondaj kuyusu mevcuttur. Bunlardan, 75 adedi araştırma amaçlı, 2362 adedi içme-kullanma amaçlı, 32 adedi sanayi suyu temini amacıyla ve 6228 adedi tarımsa sulama amaçlı açılmıştır (DSİ, 2018).

\subsection{Litolojik Birimlerin Hidrojeolojik Özellikleri (Hydrogeological Properties of Lithological Units)}

Çalışma alanında bulunan litolojik birimler, hidrojeolojik özelliklerine göre tekrar değerlendirilerek sınıflandırılmış ve bölgenin hidrojeoloji haritası hazırlanmıştır (Şekil 3). Araştırma konusunu oluşturan alanda yer alan jeolojik birimler fiziksel ve hidrojeolojik özellikleri ile akifer olabilme potansiyelleri bakımından gözenekli geçirimli birim, karstik geçirimli birim, Yarı geçirimli birim ve Az geçirimli birim olmak üzere dört ayrı grupta incelenmiştir. Çalışma alanında yüzeyleyen her bir jeolojik birimin litolojik özellikleri ve hidrojeolojik yapıları aşağıda ayrıntılı olarak açıklanmıştır.

Gözenekli Geçirimli Birim: Çalışma alanında alüvyonlar Sacir, Tüzelsuları ile eski ve yeni yatakları ile yan kolları çevresinde yüzeylenirler. Sı̆̆ kalınlıkta olmakla beraber içerdiği çakıl, kum, çakıltaşı, kumtaşı gibi gözenekli geçirimli birimler nedeniyle akifer özelliğindedir. Kalınlı̆̆ının fazla olmaması nedeniyle yağışlardan ve akarsulardan bünyesine aldığı yeraltısuyunu boşluklarda bulundurması ile birlikte alttaki birimlere ileten beslenme kayacı niteliğindedir. Çalışma alanında Sacirsuyu çayı ve Tüzelsuyu derelerin vadileri ve yan kolları vadilerinde toplam $362,09 \mathrm{~km}^{2}$ alanda alüvyon birim yüzeylenmektedir ve birim içinde açılmış olan çok sayıda sondaj kuyusu bulunmaktadır. 
Karstik Geçirimli Birim: Çalışma alanında yüzeyleyen Miyosen yaşlı kireçtașı ve Eosen yaşlı tebeşirli kireçtaşıkavkılı kireçtaşı birimleri karstik yapıları sebebiyle "Karstik Geçirimli Birim” olarak sınıflandırılmıştır. Çalışma alanının kuzeybatı ve batısında yüzeylenen Eosen Yaşlı Tebeşirli Kireçtaşı-Kavkılı Kireçtaşı biriminin, bölgede meydana gelen tektonik hareketler sonucu karstik yapı kazanan, genellikle yükseltileri oluşturan, kavkılı kireçtaşlarından oluşan üst seviyeleri, litolojik yapısı nedeniyle akifer kayacı özelliğindedir. Düșük topografyada yüzeylenen kavkılı kireçtaşlarının yeterli kalınlıktaki taban seviyeleri ile tebeşirli kireçtaşları seviyeleri akifer özelliği gösterirler. Akiferin geçirimsiz taban kayacı, açık gri, kahve renkli çakıltaşı, milli, killi, çört-marn ardalanmasından oluşur. Düşük topografyada tarımsal sulama ve içme-kullanma suyu temini için Sarıbaşak, Cebeler, Yamaçtepe, Kürüm ve Ozanlı mahalleleri çevrelerinde kavkılı kireçtaşı ve kırıntılı kireçtaşı ara bantlı tebeşirli kireçtaşları geçilen 100-200 m arasında açılan sondaj kuyularından 2-10 l/s arasında değișen debilerde yeraltısuyu üretimi yapılmaktadır. Sondaj kuyuları verimleri, geçilen kırık ve çatlak sistemlerinin oranlarına göre değişiklik gösterirler. İçme-kullanma suyunun temini için açllan Cebeler Mahallesi kuyusunda $60 \mathrm{~m} \mathrm{düşümle} 2 \mathrm{l} / \mathrm{s}$, Sarıbaşak mahallesi kuyusunda $50 \mathrm{~m}$ düşümle $3 \mathrm{l} / \mathrm{s}$, Kürüm mahallesi kuyusunda $20 \mathrm{~m}$ düşümle $10 \mathrm{l} / \mathrm{s}$ verim alınmıştır. Eosen yaşlı birimlerin toplam alanı 77,69 km²'dir (DSİ, 2018).

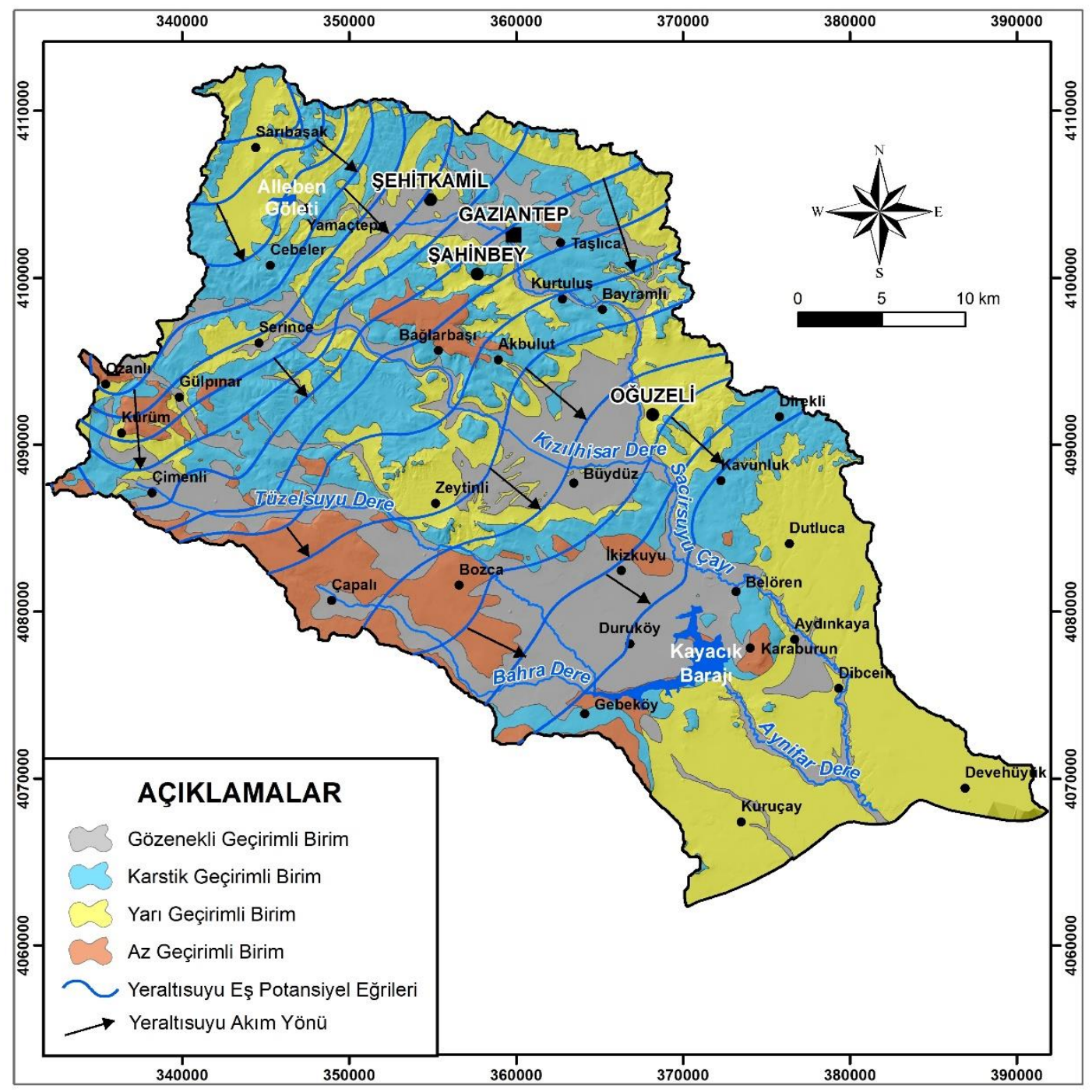

Şekil 3. Çalışma alanının hidrojeoloji haritası (Hydrogeological map of the study area)

Çalıșma alanında oldukça geniş alanda yüzeylenen litolojik yapısı nedeniyle akifer kayacı olan Miyosen kireçtaşları, en kalın olarak alt havzanın kuzey doğusunda Küçük Göllüce damları ile güney doğuda Karadibek, Sütlüce, Yeniköy, Kaşyolu, Yakacık, Gündoğan, Karataş mahalleleri çevrelerinde akifer özelliği taşırlar. Düşük topografyada yeterli kalınlıkta geçilen kırık ve çatlakların oranlarına göre 100-150 m arasında değișen derinliklerde araştırma, içme suyu ve tarımsal sulama amaçlı açılan sondaj kuyularında yeraltısuyu üretimi yapılmaktadır. Alt havzanın batısında Burçkarakuyu, Geneyik, Muhacirosman mahalleleri çevrelerinde yüzeylenen kireçtaşları topoğrafik olarak üst kotlarda yer alması ve yeterli kalınlıkta olmaması nedenleriyle daha çok beslenme kayacı özelliği taşır. Alt havzada genelinde, Miyosen yaşlı kireçtaşlarından yukarıda bahsedilen alanlar haricinde topoğrafik konumu, kalınlığı, kat edilen kırık-çatlak oranlarına göre tarımsal sulama ve kullanma amaçlı 
açılan şahıs kuyularından 0,5-2 l/s arasında değişen debilerde yeraltısuyu üretimi yapılmaktadır. Miyosen yaşlı kireçtaşlarının toplam yayılım alanı 312,42 km²'dir (DSİ, 2018).

Yarı Geçirimli Birim: Çalışma alanında yüzeyleyen Oligosen yaşlı marn-killi kireçtaşları-tebeşirli kireçtaşları, Pliyo-Kuvaterner yașlı çakıltașı-kumtașı-çamurtașı birimleri ve Paleosen yașlı killi kireçtașı-marn-kumtașı arabantlı marn birimleri yer yer geçirimsiz seviyeler içerdiğinden "Yarı Geçirimli Birim" olarak sınıflandırılmıştır. Çalışma alanında marnlı birimlerin üst seviyelerini oluşturan kumtaşı arabantlı tebeşirli-killi kireçtaşları kısmen akifer özelliği gösterirler. Akiferin geçirimsiz taban kayacı birimin marnlı seviyelerinden oluşur. Kumtaşı arabantlı tebeşirli kireçtaşlarının yeterli kalınlık gösterdiği çalışma alanın Alleben dere ve Sacirsuyu çayının vadisinde uygun topografyada 22-220 m arasında açılan sondaj kuyularından yeraltısuyu üretimi yapılmaktadır. Alt havzanın kuzeybatısında tebeşirli killi kireçtaşlarının yüzeylendiği Yamaçtepe mahallesi batısında ve Sarısalkım mahallesi güneyinde Pancarlı mevkiinde araştırma amaçlı açllan ve Alleben Göleti rezervuarında kalan tebeşirlikilli kireçtaşlarının kırık ve çatlaklı seviyeleri geçilen sondaj kuyusunda 10,4 m düşümle 45 l/s yeraltısuyu üretilmiş, kırık ve çatlak seviyeleri geçilmeyen sondaj kuyularından yeraltısuyu alınamamıştır (DSİ, 2018).

Çalışma alanının orta, doğu ve güney bölgelerine doğru Oligosen yaşlı birimlerin orta ve tabana yakın genelde marnlı seviyelerinin yüzeylenmesi nedeniyle yeterli kalınlıkta ve kırık-çatlaklı seviyelerin geçilme oranlarına göre 1-5 l/s arasında değişen debilerde yeraltısuyu alınmaktadır. Oligosen yaşlı birimlerin yayılım alanı 426,85 km²'dir. Çalışma alanının güneydoğusunda Ekinveren, Dikmetaş, Kabaağaç, Çatalçam, Hatunlu mahalleleri ve çevrelerinde Pliyokuvaterner birimleri yüzeylenir. Çakıltaşı, kumtaşı gibi geçirimli-yarı geçirimli seviyeler içermekle beraber killi seviyelerde içerdiğinden homojen akifer özelliği göstermez. Geçirimli seviyelerin yeterli kalınlıkta olduğu alanlarda açılan sondaj kuyuları vasıtasıyla çok az miktarda da olsa yeraltısuyu alınmaktadır. Tarımsal sulama amaçlı şahıslar tarafından açılan 80-100 m derinlikteki kuyular vasıtasıyla kuyularda kat edilen geçirimli- yarı geçirimli birimlerin kalınlıkları ile orantılı olarak 0,5-1,5 l/s yeraltısuyu üretimi yapılmaktadır. Birimin yayılım alanı 69,96 km²'dir (DSİ, 2018).

Az geçirimli birim: Çalışma alanında yüzeyleyen Miyosen-Pliyosen yaşlı bazalt ve çakılltaşı, kumtaşı, şeyl birimlerinden oluşan filiş birimleri "Az Geçirimli Birim” olarak sınıflandırılmıştır. Çalışma alanının Akbulut, Bağlarbaşı mahalleleri, Küçük Karataş, Kara Taşlık çevreleri ile alt havzanın güney-güneybatısında Killik, Çatalsu, Töreli, Çapalı mahalleleri ve Tüzel suyu ve Bahre dere vadisinde bazalt birimleri yüzeylenir. Bazaltlar; oluşum esnasında kazandıkları gözenekli ve tektonik hareketler sonucunda oluşan kırıklı ve çatlaklı yapıları nedeniyle bilhassa, Tüzelsuyu vadisinde kısmen akifer özelliği taşırlar. Yeterli kalınlıkta olduğu düşük topografyada 80-100 m arasında değişen derinliklerde açılan şahıs kuyularından tarımsal sulama amaçlı yeraltısuyu üretimi yapılır. DSİ tarafindan alt havzada 1-132 m kalınlıkta Pliyokuvaterner birimlerinden sonra girilen 132-250 m'ler arasında 118 m bazaltta ilerlenen, bazaltlar içerinde sonlandırılan sondaj kuyusunda 57,18 m düşümle 0,9 l/s yeraltısuyu alınmıştır. Çoğunlukla Tüzelsuyu vadisinde 80-110 m arasında değişen derinliklerde şahıslar tarafından tarımsal sulama amaçlı açılan kuyular vasıtasıyla da geçilen bazaltların kalınlığı ve kırık-çatlak seviyelerinin oranlarına göre 0,5-2,5 l/s yeraltısuyu üretimi yapılmaktadır. Birimin yayılım alanı 134,51 km²'dir (DSİ, 2018).

Çalışma alanındaki sondaj kuyularında ölçülmüş yeraltısuyu seviyesi değerleri DSİ (2018)'den temin edilmiştir. Bölgede yeraltısuyu derinlikleri 1.05- $39 \mathrm{~m}$ arasında değişmekte olup yeraltısuyu statik seviyeleri ise $545 \mathrm{~m}$ ile $679 \mathrm{~m}$ arasında değişmektedir. Çalışma alanında yeraltısuyu eş potansiyel eğrilerine göre yeraltısuyu akımı genellikle kuzeybatıdan güney doğuya, Kayacık Baraj gölüne doğrudur (Şekil 3). DSİ (2018) tarafından yapılan

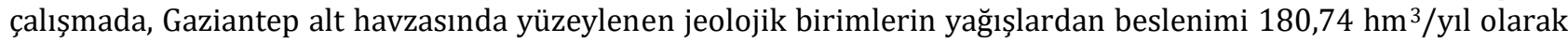
hesaplanmıştır. Kaynaklardan gerçekleşen yeraltısuyu boşalımı 31,43 hm³ $/$ yıl; içme-kullanma-sanayi kullanımı için alınan yeraltısuyu miktarı 23,15 hm³/yıl; tarımsal sulama amaçlı sondaj kuyularından gerçekleşen yeraltısuyu boşalımı ise $106,29 \mathrm{hm}^{3} /$ yıl olarak belirlenmiştir. Beslenim ve boşalım farklı olarak belirlenen $19,87 \mathrm{hm}^{3} / \mathrm{yll}$ yeraltısuyunun ise içe akış ile Suriye'ye boșaldığı belirtilmektedir.

\subsection{Hidrojeokimyasal Özellikler (Hydrogeochemical Properties)}

Çalıșma alanında yer alan yeraltısularının kalitesi, kullanım koşulları, kökeni ve hidrojeokimyasal özelliklerinin belirlenmesi amaciyla, Mayıs-2017 döneminde, 15 adet sondaj kuyusu ve 6 adet kaynaktan (Karpuzatan-G11, Kırkgöz-G13, Enebacı-G17, Akpınar-G19, Çapalı-G20, Aynafar-G21) su örnekleri alınarak analizler yaptırılmıştır (Şekil 4). Su örneklerinin kimyasal analiz sonuçlarının istatistiksel özeti Tablo 1'de verilmiştir. Örnekleme sırasında Elmetron CX-401 ve YSI Professional Plus marka çok parametreli taşınabilir su kalitesi ölçüm cihazları kullanılarak yerinde ölçümler yapılmıştır. Yeraltısuyu örneklerinin \% iyon dağılım grafikleri Şekil 5’de verilmiştir. Yeraltısuyunun hidrojeokimyasal özelliklerinin tanımlanmasında, genel kimyasal özellikler değerlendirilmiş ve Schoeller (1955), Piper (1944), Chadha (1999) ve Gibbs (1970) diyagramları kullanılarak değerlendirmeler yapılmıştır. Su örneklerinin kimyasal analizlerinin doğruluğunu kontrol etmek için hesaplanan yük denge hatası $<\% 5$ olup kabul edilebilir sınırlar içerisindedir. Çalışma alanında yer alan yeraltısularının kullanım amaçlarının 
değerlendirilmesinde ise ulusal ve uluslararası standartların yanı sıra ABD tuzluluk laboratuvarı diyagramı kullanılmıștır.

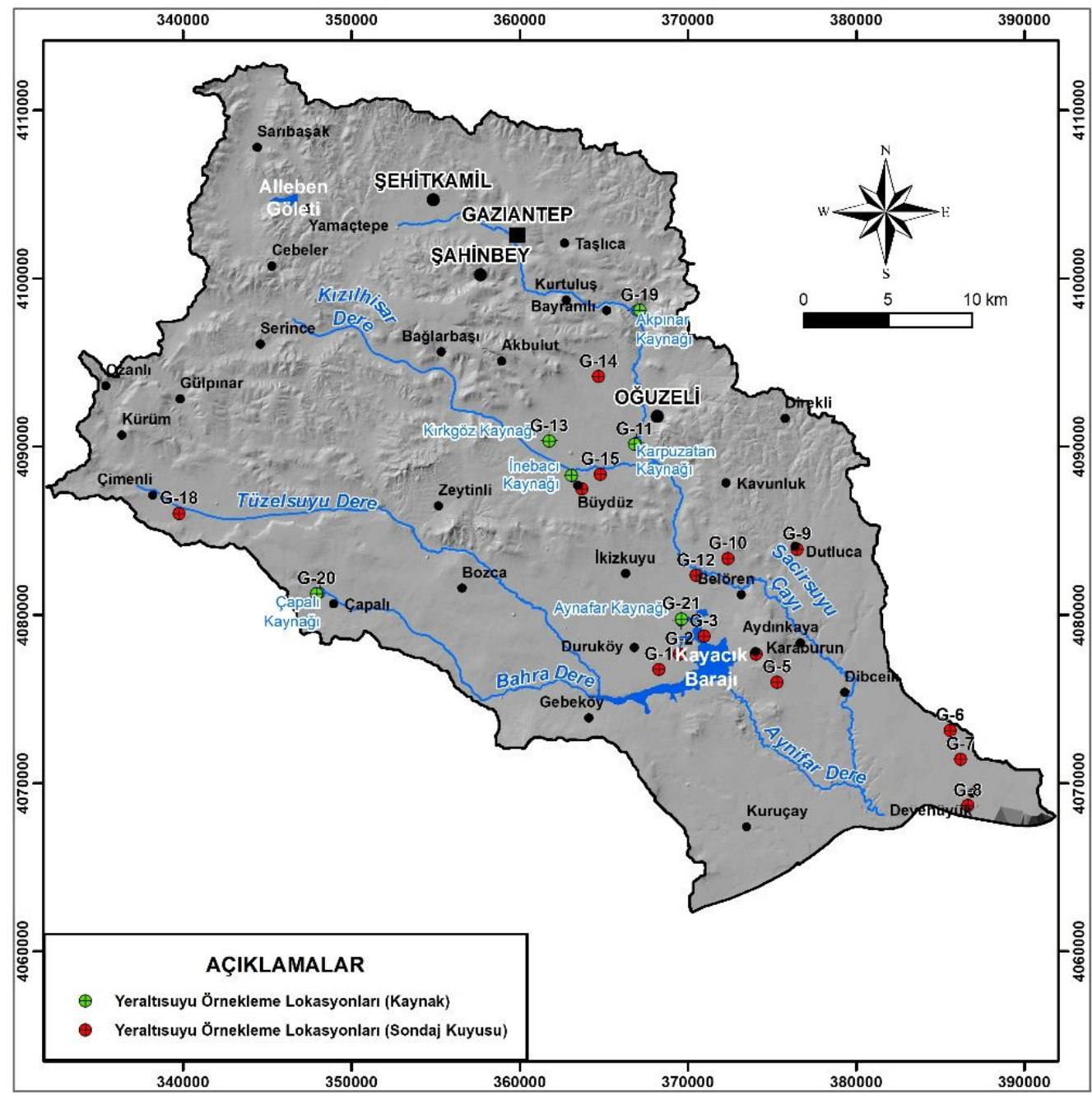

Şekil 4. Su örnekleri lokasyon haritası (Location map of the water samples)

Tablo 1. Su örneklerinin kimyasal analiz sonuçları (Chemical analysis results of water samples)

\begin{tabular}{|c|c|c|c|c|c|c|c|c|}
\hline Parametre & Birim & $\begin{array}{c}\text { Örnek } \\
\text { saylsi }\end{array}$ & Minimum & Maksimum & Ortalama & $\begin{array}{c}\text { Standart } \\
\text { Sapma }\end{array}$ & $\begin{array}{c}\text { TS266 } \\
\mathbf{( 2 0 0 5 )} \\
\mathbf{m g} / \mathbf{l}\end{array}$ & $\begin{array}{c}\text { WHO } \\
\mathbf{( 2 0 0 8 )} \\
\mathbf{m g} / \mathbf{l}\end{array}$ \\
\hline $\mathbf{p H}$ & & 21 & 7.13 & 8.20 & 7.57 & 0.32 & $6.5-9.5$ & $6.5-8.5$ \\
\hline $\mathbf{E C}$ & $(\mu \mathrm{S} / \mathrm{cm})$ & 21 & 405.00 & 1154.00 & 661.00 & 185.82 & & \\
\hline $\mathbf{T D S}$ & $(\mathrm{mg} / \mathrm{L})$ & 21 & 234.33 & 692.40 & 393.45 & 111.18 & & 1000.00 \\
\hline $\mathbf{N a}$ & $(\mathrm{mek} / \mathrm{l})$ & 21 & 0.14 & 1.72 & 0.80 & 0.51 & 200.00 & 200.00 \\
\hline $\mathbf{K}$ & $(\mathrm{mek} / \mathrm{l})$ & 21 & 0.02 & 0.15 & 0.80 & 0.48 & & \\
\hline $\mathbf{C a}$ & $(\mathrm{mek} / \mathrm{l})$ & 21 & 2.19 & 8.13 & 4.65 & 1.39 & & 200.00 \\
\hline $\mathbf{M g}$ & $(\mathrm{mek} / \mathrm{l})$ & 21 & 0.37 & 2.46 & 1.09 & 0.54 & & \\
\hline $\mathbf{H C \mathbf { O } _ { 3 }}$ & $(\mathrm{mek} / \mathrm{l})$ & 21 & 3.25 & 7.35 & 4.70 & 0.96 & & \\
\hline $\mathbf{C l}$ & $(\mathrm{mek} / \mathrm{l})$ & 21 & 0.15 & 4.71 & 0.92 & 1.05 & 250.00 & 250.00 \\
\hline $\mathbf{S \mathbf { O } _ { 4 }}$ & $(\mathrm{mek} / \mathrm{l})$ & 21 & 0.18 & 1.02 & 0.48 & 0.21 & 250.00 & 250.00 \\
\hline $\mathbf{N \mathbf { O } _ { 2 }}$ & $(\mathrm{mg} / \mathrm{L})$ & 21 & 0.23 & 1.99 & 1.65 & 0.71 & 0.50 & 3.00 \\
\hline $\mathbf{N \mathbf { O } _ { 3 }}$ & $(\mathrm{mg} / \mathrm{L})$ & 21 & 8.42 & 87.40 & 32.11 & 21.94 & 50.00 & 50.00 \\
\hline $\mathbf{A l}$ & $(\mu \mathrm{g} / \mathrm{l})$ & 21 & 5.32 & 93.22 & 31.52 & 37.17 & 0.20 & 0.20 \\
\hline $\mathbf{M n}$ & $(\mu \mathrm{g} / \mathrm{l})$ & 21 & 6.34 & 35.31 & 20.93 & 13.19 & 0.05 & 0.4 \\
\hline $\mathbf{C u}$ & $(\mu \mathrm{g} / \mathrm{l})$ & 21 & 28.72 & 49.99 & 40.40 & 8.28 & 2.00 & 2.00 \\
\hline $\mathbf{Z n}$ & $(\mu \mathrm{g} / \mathrm{l})$ & 21 & 20.72 & 38.14 & 28.32 & 6.85 & - & - \\
\hline $\mathbf{P b}$ & $(\mu \mathrm{g} / \mathrm{l})$ & 21 & 1.32 & 4.53 & 2.95 & 1.32 & 0.01 & 0.01 \\
\hline $\mathbf{A s}$ & $(\mu \mathrm{g} / \mathrm{l})$ & 21 & 0.81 & 1.30 & 1.16 & 0.24 & 0.01 & 0.01 \\
\hline $\mathbf{F e}$ & $(\mu \mathrm{g} / \mathrm{l})$ & 21 & 94.97 & 919.40 & 314.60 & 341.91 & 0.20 & - \\
\hline $\mathbf{C r}$ & $(\mu \mathrm{g} / \mathrm{l})$ & 21 & 1.09 & 3.76 & 2.41 & 1.27 & 0.05 & 0.05 \\
\hline $\mathbf{N i}$ & $(\mu \mathrm{g} / \mathrm{l})$ & 21 & 11.14 & 17.60 & 12.82 & 2.77 & 0.02 & 0.07 \\
\hline
\end{tabular}


Çalışma alanındaki su örneklerinin pH değerleri 7.13 - 8.20 arasında olup genel olarak "Bazik karakterli” sular sınıfında yer almaktadır. Kaynak sularının pH değerleri ise 7.13 - 7.67 arasındadır ve bazik karakterli sulardır. Bu durum sularda bikarbonat iyonunun baskın olmasından kaynaklanmaktadır. Çalışma alanından alınan su örneklerinin özgül elektriksel iletkenlik değerleri yerinde ölçümler ile belirlenmiș olup 405-1154 $\mu \mathrm{S} / \mathrm{cm}$ arasında değişmektedir. Kaynak suları ise $452-844 \mu \mathrm{S} / \mathrm{cm}$ arasında EC değerine sahiptir. G12, G14, G15 ve G21 nolu su örneklerinde iyon bolluğuna bağlı olarak diğer örneklerden daha yüksek miktarlarda EC değeri ölçülmüştür. EC değerinin yüksek ölçüldüğü örneklerde kalsiyum, magnezyum ve nitrat miktarlarının diğer örneklere nazaran daha yüksek olduğu görülmektedir. Buna göre kaya-su etkileşimi ile birlikte tarımsal kirliliğin de EC değerlerinin yüksek olmasında etkili olduğunu söylemek mümkündür.

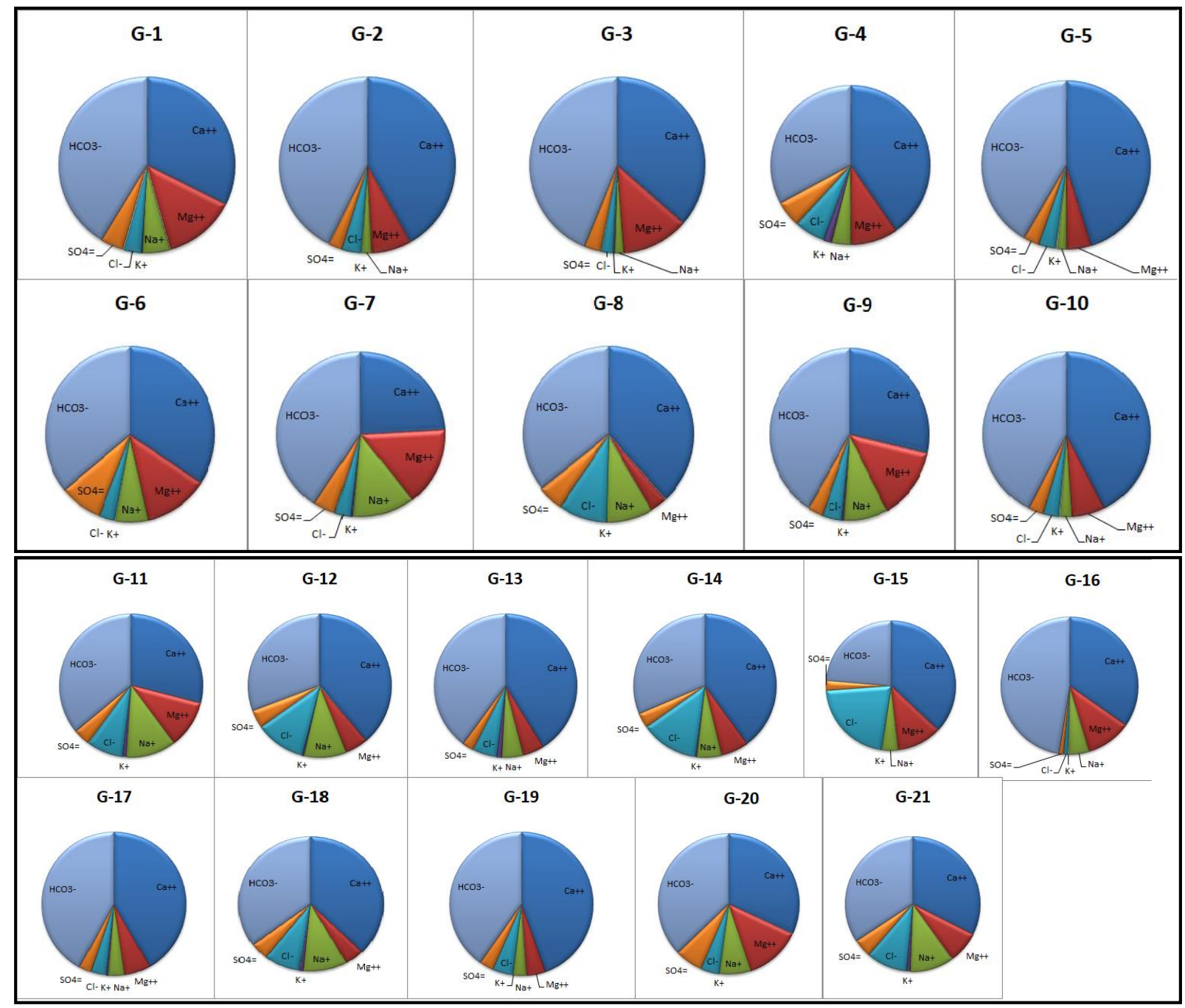

Şekil 5. Yeraltısuyu örneklerinin \% iyon dağllım grafikleri (Ion distribution graphs of groundwater samples)

\subsection{Suların Hidrojeokimyasal Sinıflaması (Hydrogeochemical Classification of Waters)}

Schoeller (1955) yapmış olduğu sınıflandırmada suları klorür, sülfat ve karbonat miktarlarına göre sınıflandırmıştır (Tablo 2). Schoeller (1955)'in yapmış olduğu sınıflamaya göre alınan su örneklerinin hepsi Klorür derişimi bakımından "olağan klorürlü sular" sınıfına, sülfat derişimi bakımından "olağan sülfatlı sular" sınıfında yer almaktadır. Karbonat-Bikarbonat derişimi bakımından ise G-16 nolu örnek "Hiperkarbonatlı Sular" sınıfında, diğer tüm örnekler ise "olağan karbonatlı sular" sınıfında yer almaktadır. 
Tablo 2. Schoeller (1955) klorür, sülfat, karbonat-bikarbonat sinıflaması (Schoeller (1955) classification of chloride, sulfate, carbonate-bicarbonate)

\begin{tabular}{|c|c|c|}
\hline \multirow{7}{*}{ 竎 } & Su sinıfi & Klorür Miktarı (mek/l) \\
\hline & Hiperklorürlü Sular & $>700$ \\
\hline & Klorotalasik Sular & $420-700$ \\
\hline & Klorürce Zengin Sular & $140-420$ \\
\hline & Orta Klorürlü Sular & $40-140$ \\
\hline & Oligoklorürlü Sular & $15-40$ \\
\hline & Olağan Klorürlü Sular & $<15$ \\
\hline \multirow{5}{*}{ 营 } & Su sinıfi & Sülfat Miktarı (mek/l) \\
\hline & Hiposülfatlı Sular & $>58$ \\
\hline & Sülfatlı Sular & $24-58$ \\
\hline & Oligosülfatlı Sular & $6-24$ \\
\hline & Olağan Sülfatlı Sular & $<6$ \\
\hline \multirow{4}{*}{ 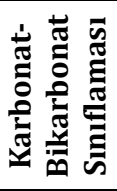 } & Su sinıfı & $\begin{array}{c}\text { Karbonat+Bikarbonat Miktarı } \\
(\mathrm{mek} / \mathrm{l})\end{array}$ \\
\hline & Hiperkarbonatlı Sular & $>7$ \\
\hline & Olağan Karbonatlı Sular & $2-7$ \\
\hline & Hipokarbonatlı Sular & $<2$ \\
\hline
\end{tabular}

Çalışma alanındaki yeraltısuyu örneklerine ait analiz sonuçları Piper diyagramı üzerinde gösterilerek su örneklerinin hidrojeokimyasal fasiyesleri belirlenmiștir (Şekil 6). Piper (1944) diyagramı suların genel anyonkatyon içeriğini dikkate alarak su fasiyeslerinin belirlenmesinde kullanılmaktadır. Yeraltısuyu örneklerinin genel olarak $\mathrm{Ca}-\mathrm{HCO}_{3}$ ve Ca-Mg- $\mathrm{HCO}_{3}$ 'lü sular fasiyesinde olduğu görülmektedir. Çalışma alanındaki su kaynakları genel olarak kireçtaşı ve dolomit gibi karbonatlı kayaçlar ile etkileşim halindedir ve baskın su tiplerinin söz konusu kayaç-su etkileşimi sonucunda geliştiği görülmektedir.

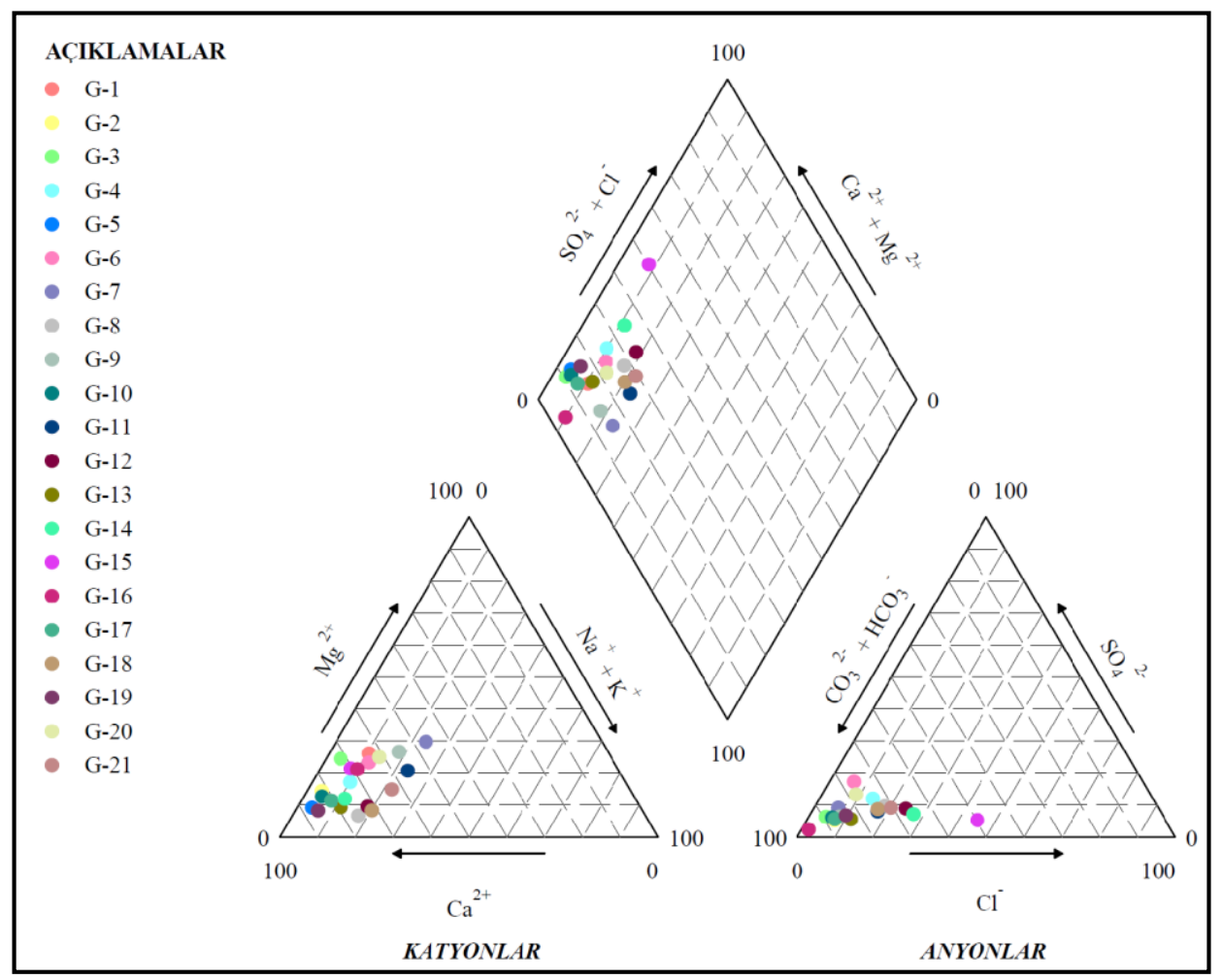

Şekil 6. Piper diyagramı (Piper diagram)

Ayrıca, su örneklerinin anyon ve katyon değerleri Chadha Diyagramı (1999) üzerine yerleștirilerek suların hidrojeokimyasal özellikleri yorumlanmıştır (Şekil 7). Bu diyagram, Piper Diyagramının (1944) değiștirilmiş halidir. Farkı ise, iki eşkenar üçgenin çıkarılmış olmasıdır. Hazırlanan Chadha diyagramına göre, alınan tüm su örnekleri Ca-Mg- $\mathrm{HCO}_{3}$ su tipindedir. Su tipleri tamamen kaya-su etkileşiminin bir sonucu olup $\mathrm{Ca}-\mathrm{Mg}^{-} \mathrm{HCO}_{3}$ su tipini havza içerisindeki kalkerli kayaçların varlığı ile açıklamak mümkündür. Çalışma alanında belirlenen su tipinin hangi işlev ve/veya mekanizma sonucu değiştiğini belirleyebilmek için ise su örneklerinin iyonik oranları Gibss Diyagramı üzerine yerleştirilmiştir. Gibss Diyagramında, su örneklerinin tamamı "Kayaç Baskın” bölgesine 
düşmektedir (Şekil 8). Bu da, su kimyasını kontrol eden ana mekanizmanın, kayaç yapıcı minerallerin kimyasal ayrışması olduğunu göstermektedir.

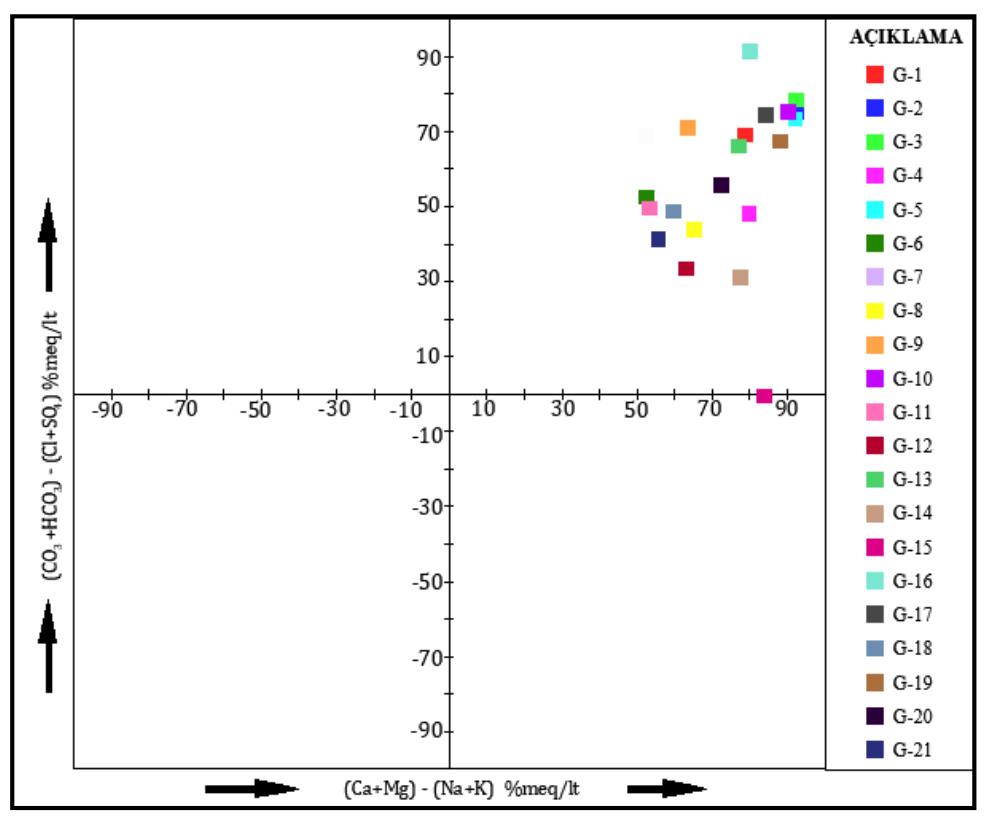

Şekil 7. Chadha diyagramı (Chadha diagram)

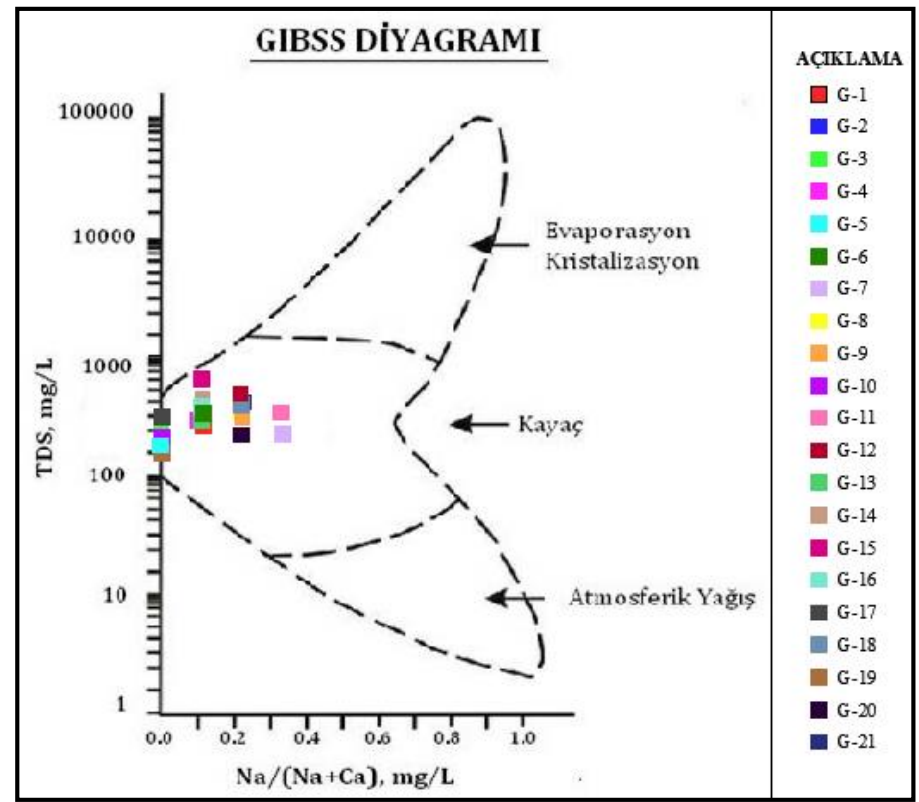

Şekil 8. Gibbs diyagramı (Gibbs diagram)

\subsection{Suların Kullanım ve Kalite Özellikleri (Usage and Quality Characteristics of Waters)}

Çalıșma alanından alınan su örneklerinin kullanım özelliklerinin değerlendirilmesinde öncelikle analiz sonuçları TSE-266 (2005) ve Dünya Sağlık Örgütü (WHO, 2008) tarafından belirtilen içme suyu limit değerleri ile karşılaştırılmıştır (Tablo 1). Buna göre, G11 ve G18 nolu su örnekleri Fe bakımından, G4, G12 ve G15 nolu su örnekleri ise $\mathrm{NO}_{3}$ bakımından içme suyu limit değerlerin üzerinde olup içme suyu olarak kullanıma uygun değildir. Yüksek Fe değerinin ölçüldügü su örnekleri alüvyon ve karstik akiferden beslenen Karpuzatan Kaynağı (G11) ve G18 nolu sondaj kuyusundan alınmış olup bulundukları lokasyonlarda yüksek Fe içeriğine sebep olabilecek antropojen kökenli kirleticiler bulunmamaktadır. Bu durum, örneklerin kayaç-su etkileşimi sonucunda yüksek Fe konsantrasyonuna sahip olabileceği ihtimalini güçlendirmektedir. Su örneklerinde belirlenen nitrat artışlarının ise daha çok tarımsal faaliyetler ile ilişkili olduğu düşünülmektedir.

Çalışma alanındaki sularının sulamada kullanılabilirliğini belirlemek için sular Sodyum Adsorbsiyon Oranlarına (SAR) ve Özgül Elektriksel İletkenlik (EC) değerlerine göre sınıflandırılmıştır. Ayrıca, ABD Tuzluluk Laboratuvarı Diyagramı kullanılarak suların sulamada kullanılabilirliği tartışılmıştır. Çalışma alanındaki yeraltısularının analiz 
sonuçları kullanılarak hesaplanan SAR değerleri genel olarak 0.14 ile 1.34 arasında değişmekte olup 'çok iyi özellikte sulama suları' sınıfına girmektedir. Sular toplam tuz içeriğine göre ise $405-1154 \mu \mathrm{S} / \mathrm{cm}$ arasında ölçülmüş olan EC değerlerine göre 'orta-yüksek tuzlu sular' sınıfında yer almaktadır.

ABD Tuzluluk Laboratuvarı Diyagramı'na göre yapılan sınıflamada su örneklerine ait SAR ve özgül elektriksel iletkenlik değerleri kullanılmıștır (Şekil 9). Buna göre, çalışma alanındaki su örneklerinin tümü 'C2S1 ve C3S1' sınıfındadır. Kaynak sularından ise sadece Aynafar kaynağı C3S1 sınıfında yer almaktadır. Bu sonuç çalışma alanı ve yakın çevresindeki suların genel anlamda orta-fazla tuzlu olup sodyuma karşı duyarlı bitkiler dışında kullanılabilecek özellikte sular olduğunu göstermektedir.

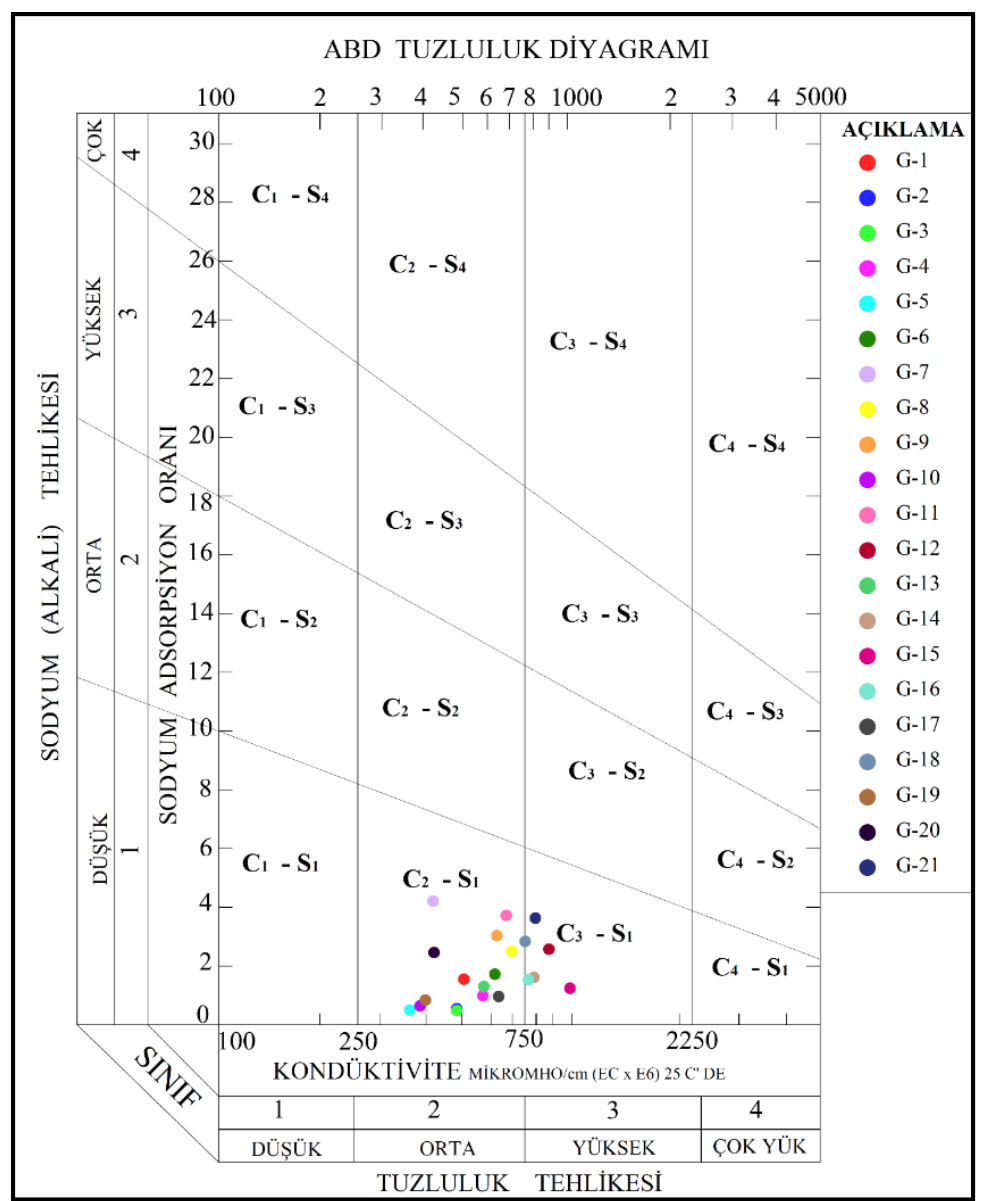

Şekil 9. ABD Tuzluluk Laboratuvarı Diyagramı (U.S. Salinity Laboratory Diagram)

\section{Sonuç ve Tartışma (Result and Discussion)}

Gaziantep ili içme suyu ihtiyacının karşılandı̆̆ı yeraltısuları bölgedeki gözenekli ve karstik akifer birimler sağlanmaktadır. Ayrıca, kaynak suları da içme ve sulama suyu olarak kullanılmaktadır. Yapılan çalışmada çalışma alanındaki yeraltısuyu ve kaynak sularının iyon özellikleri ve kalitesi incelenmiştir. Elde edilen sonuçlara göre, su örneklerinde belirlenen hakim iyonlar $\mathrm{Ca}$, $\mathrm{Mg}$ ve $\mathrm{HCO}_{3}$ 'tür. Buna bağlı olarak baskın su tipinin $\mathrm{Ca}^{-} \mathrm{HCO}_{3}$ ve $\mathrm{Ca}_{-} \mathrm{Mg}$ $\mathrm{HCO}_{3}$ olduğu belirlenmiştir. Gibss Diyagramına göre, su örneklerinin tamamı "Kayaç Baskın" bölgesinde yer almaktadır ve kayaç-su etkileşiminin su kimyasının gelişiminde etkili olduğunu ortaya koymaktadır. Analiz sonuçları TSE-266 (2005) ve Dünya Sağlık Örgütü (WHO, 2008) tarafından belirtilen içme suyu limit değerleri ile karşılaştırıldığında örneklerin $\mathrm{Fe}$ ve $\mathrm{NO}_{3}$ parametreleri bakımından içme suyu olarak kullanıma uygun olmadığı belirlenmiştir. Sularda nitrat artışı ise daha çok tarımsal kirleticiler ile ilişkilidir. Sular sulama suyu kullanımı bakımından incelendiğinde ise genel olarak orta-yüksek tuzluluğa sahip sular sınıfında olduğu ve tarımsal sulamada kullanımında kısıtların olduğu görülmektedir. Genel olarak çalışma alanında su kaynaklarının kalitesini etkileyen ve kullanımlarını kısıtlayan tarımsal kirleticilerin kontrol altına alınması önerilmektedir.

\section{Teşekkür}

Bu çalışma Süleyman Demirel Üniversitesi Bilimsel Araştırma Projeleri Koordinasyon Birimi tarafından 4895 YL1-17 kodlu (ID:4451) münferit araştırma projesi kapsamında desteklenmiştir. Yazarlar, çalışmayı finansal olarak destekleyen SDÜ Bilimsel Araştırma Projeleri Yönetim Birimi Başkanlığı'na teşekkür ederler. 


\section{Çıkar Çatışması (Conflict of Interest)}

Yazarlar tarafından herhangi bir çıkar çatışması beyan edilmemiştir. No conflict of interest was declared by the authors.

\section{Kaynaklar (References)}

Alan, E. 2017. Gaziantep İli Şehitkamil İlçesi Yeditepe Mahallesi İçme Suyu Şebeke Tasarımı (Master's thesis, İstanbul Gelişim Üniversitesi Fen Bilimleri Enstitüsü), $83 \mathrm{~s}$.

Bozdă̆, A., Göçmez, G. 2013. Evaluation of groundwater quality in the Cihanbeyli basin, Konya, Central Anatolia, Turkey, Environmental Earth Sciences, 69(3), 921-937.

Bozdă̆, A. 2017. Çumra (Konya) Ovasındaki Yeraltısularının Hidrojeokimyasal Özellikleri ve Sulama Suyu Kalitesi, Mühendislik Bilimleri ve Tasarım Dergisi, 5(3), 559-571.

Bozdağ, A. 2016. Assessment of the hydrogeochemical characteristics of groundwater in two aquifer systems in Çumra Plain, Central Anatolia, Environmental Earth Sciences, 75(8), 674.

Chadha, D.K., 1999. A Proposed New Diagram For Geochemical Classification of Natural Water sand Interpretation of Chemical Data. Hdrogeology Journal, 7, 431-439.

Çiftçi, H. 201). Investigation of feasibility for Gaziantep earthquake master plan. Yüksek Lisans Tezi, Hasan Kalyoncu Üniversitesi, $57 \mathrm{~s}$.

DSİ 2018. Gaziantep-Kilis Ovaları Hidrojeoloji Etüt Raporu Yapılması ve Yaptırılması İși, DSİ 20. Bölge Müdürlüğü, Kahramanmaraş.

Fırat Ersoy, A., Gültekin, F. 2013. DRASTIC-based methodology for assessing groundwater vulnerability in the Gümüshaciköy and Merzifon basin (Amasya, Turkey). Earth sciences research journal, 17(1), 33-40.

Gibbs, R., 1970. Mechanism Controlling World River Water Chemistry. Science 170,1088-1090.

Jayaprakash, M., Giridharan, L., Venugopal, S., Krishna Kumar, S.P., Periyakali, P. 2008. Characterization and evaluation of the factors affecting the geochemistry of groundwater in Neyveli, Tamil Nadu, India. Environmental Geology, 54(4), 855-867.

Kafadar, F. N., Saygıdeğer, S. 2010. Gaziantep ilinde organize sanayi bölgesi atık suları ile sulanan bazı tarım bitkilerinde kurșun $(\mathrm{Pb})$ miktarlarının belirlenmesi. Ekoloji, 19(75), 41-48.

MTA, 1996, 1:100.000 ölçekli Türkiye Jeoloji Haritaları, Urfa-N39 Paftası. Maden Tetkik ve Arama Genel Müdürlüğü Jeoloji Etütleri Dairesi, Ankara.

MTA, 1997, 1:100.000 ölçekli Türkiye Jeoloji Haritaları, Gaziantep-N38 Paftası. Maden Tetkik ve Arama Genel Müdürlüğü Jeoloji Etütleri Dairesi, Ankara.

Piper, A.M. 1944. A Graphic Procedure in Geochemical Interpretation of Water Analyses, American Geophysical Union Transactions 25: 914-923.

Schoeller, H., 1955. GechemieDesEauxSouterranes. ReviewInstutieFranc. Petrole, Paris, 3-4.

Srinivas, Y., Hudson Oliver, D., Stanley Raj, A., Chandrasekar, N. 2013. Evaluation of groundwater quality in and around Nagercoil town, Tamil Nadu, India: an integrated geochemical and GIS approach. Applied Water Science, 3, 631-651.

Sener E, Sener S, Davraz A. 2009. Assessment of aquifer vulnerability based on GIS and DRASTIC methods: a case study of Senirkent-Uluborlu basin (Isparta,Turkey). Hydrogeology Journal 17: 2023-2035

Şener, E., Davraz A. 2012. Assessment of groundwater vulnerability based on a modified DRASTIC model, GIS and an analytic hierarchy process (AHP) method: the case of Egirdir Lake basin (Isparta, Turkey), Hydrogeology Journal, DOI $10.1007 / \mathrm{s} 10040-012-0947-y$

Șimșek, C., Gündüz, 0. 2007. IWQ Index: A GIS-Integrated Technique to Assess Irrigation Water Quality, Environmental Monitoring Assessment, 128:277-300.

TS-266, 2005. Sular - İnsani tüketim amaçlı sular, TS-266, Türk Standartları Enstitüsü, 25 s, Ankara.

Vasanthavigar, M., Srinivasamoorthy, K., Vijayaragavan, K., Rajiv Ganthi R., Chidambaram S., Anandhan, P., Manivannan, R., Vasudevan, S., 2010. Application of water quality index for groundwater quality assessment: Thirumanimuttar sub-basin, Tamilnadu, India, Environmental Monitoring Assessment, 171:595-609.

WHO 2008. World Health Organisation Guidelines for Drinking-water Quality, Third Edition Incorporating the First and Second Addenda, WHO Publication, Geneva, 668 p. 2008. 